\title{
(Re-)Shaping a Method: Field Research and Experimental Legacy in Vallisneri's Primi Itineris Specimen (1705)
}

\author{
Francesco Luzzini
}

So wrote an excited Antonio Vallisneri to a friend of his, the physician Flaminio Corghi (16?-17?), in a letter dated June 1705:

My Alpine journey will probably come out this year and - for my part I consider it most interesting, given the new medical and physical things which I have observed in those mountains. It will be [written] in Plinian Latin, and first will be submitted to the eyes of the [reviewer], and then it will be published. In light of the furious work I have done, you will see that my Latin style has changed completely. ${ }^{1}$

The work had been "furious" indeed, considering what we now know about this matter. And such was Vallisneri's enthusiasm for the content of his manuscript that, in early February of the same year, he had sent a copy of it to Sir Hans Sloane (166o-1753), secretary of the Royal Society of London and editor of the Philosophical Transactions: he was hoping that this report (entitled Primi Itineris per Montes Specimen Physico-Medicum, "Physico-Medical Example of a First Journey through the Mountains") would be published in that august journal, allowing him to thrust himself into the forefront of the European Republic of Letters.

Alas, events went differently. The manuscript was never published, and the reasons for this missed opportunity are shrouded in speculation - although both the considerable length of the text and the fact that it was written in Latin

1 Antonio Vallisneri, Epistolario, vol. I (1679-1710), ed. Dario Generali (Milan: Franco Angeli, 1991), 322: "Uscirà forse quest'anno il mio viaggio alpino, che per me stimo curiosissimo, per le cose mediche e fisiche osservate di nuovo in quelle Alpi. Sarà in latino pliniano, e passerà prima sotto gli occhi del Davino, e poi uscirà. Vedrete mutata affatto la mia maniera latina, per lo studio rabbioso che vi ho fatto." My translation here and throughout. 
are the most plausible culprits. In fact, by the early eighteenth century the Royal Society tended to favour the publication of English-language papers. It is perhaps not by chance that in a letter dated March 9, 1710, Vallisneri declared to Sloane that his works were for the most part "written in the Italian language." Presumably, Sloane had asked him for an English (or, at least, a shorter Latin) version of the manuscript, which he could - or would - not provide. ${ }^{3}$

Whatever the causes, the consequences of this unfortunate setback turned out to be unmistakably negative. The missed publication doomed the manuscript to oblivion, and the document disappeared from sight. Supposedly, this precious paper still lingers in the hallways of the Archives of the Royal Society of London, although there is no trace of it in the collections database. Thus, for a long time the only known and most complete surviving records of Vallisneri's journey were two Italian summaries of the original version, the Estratti ("Extracts"), published in 1722 and 1726 in the Supplementi al Giornale de' Letterati d'Italia. ${ }^{4}$ Even in this condensed form, however, the mass of information provided by the author was such that it was no surprise that the original text had been deemed by him worthy of international prestige. The amazingly eclectic content of the Estratti encompassed the whole range of natural sciences, including topics such as stratigraphy, mineralogy, petrography, geomorphology, palaeontology, hydrogeology, geography, technology, mining meteorology, medicine, chemistry, botany, and biology. Not to

2 Vallisneri, Epistolario, vol. I (1679-1710), 503.

3 Vallisneri's strong advocacy of the use of the Italian language by all Italian scholars (even when addressing the international audience) may have played a role in his hesitation to comply with Sloane's request. This ideal was publicly upheld in: Antonio Vallisneri, "Che ogni Italiano debba scrivere in Lingua purgata Italiana, o Toscana," Supplementi al Giornale de' Letterati d'Italia I (1722). This work is now published in: Antonio Vallisneri, Che ogni Italiano debba scrivere in Lingua purgata Italiana, ed. Dario Generali (Florence: Olschki, 2013). On this topic, see: Dario Generali, "Il testo tra comunicazione scientifica e strategie editoriali. Il caso di Antonio Vallisneri," in Edizioni e traduzioni di testi filosofici, ed. Marialuisa Baldi and Barbara Faes de Mottoni (Milan: Franco Angeli, 20o6); Generali, Antonio Vallisneri: gli anni della formazione e le prime ricerche (Florence: Olschki, 2007), 384-86; Generali, "La Repubblica delle Lettere e i carteggi scientifici: il caso di A. Vallisneri," in La Repubblica delle Lettere, il Settecento italiano e la Scuola del secolo XXI, ed. Andrea Battistini, Claudio Griggio, and Renzo Rabboni (Pisa, Rome: Fabrizio Serra Editore, 2011); Francesco Luzzini, Il miracolo inutile: Antonio Vallisneri e le scienze della Terra in Europa tra XVII e XVIII secolo (Florence: Olschki, 2013), 217-226; Rhoda Rappaport, When Geologists were Historians, 1665-176o (Ithaca: Cornell University Press, 1997), 218-219.

4 Antonio Vallisneri, "Estratto d'alcune Notizie intorno alla Provincia della Garfagnana, cavate dal primo Viaggio Montano del Sig. Antonio Vallisnieri," Supplementi al Giornale de' Letterati d'Italia II (1722); Vallisneri, "Continuazione dell'Estratto d'alcune Notizie intorno alla Garfagnana," Supplementi al Giornale de' Letterati d'Italia III (1726). 
mention, of course, the many humanistic forays which were a typical feature in texts written by early modern savants, and which embraced philosophy, history, literature, archaeology, religion, anthropology, and even material culture and folklore. In brief, there were few doubts that finding the original document would allow us both to recreate Vallisneri's travel, and to appreciate its historical and scientific value, with an accuracy unrivalled in the history of early modern naturalistic explorations.

This premonition proved to be true in 2009, when the draft copy of the Primi Itineris Specimen was fortuitously discovered by me and my mentor, Dario Generali, in the State Archive of Reggio Emilia (where the vast and still largely unexplored bulk of the author's unpublished writings - the Archivio Vallisneri, or "Vallisneri Archive" - is held)..$^{5}$ Needless to say, this finding exceeded my best expectations. And, in working my way through the content of those faded papers (fig. 3.1) and in comparing it with that from the Estratti, I realized that an exhaustive study of Vallisneri's adventure would take much longer than I had imagined. But the result was definitely worth the effort: I succeeded in recreating the itinerary almost in its entirety, and by the summer of 2010 I was also able to replicate in person Vallisneri's journey and many of his observations and explorations. ${ }^{6}$ The crowning moment of this scholarly endeavour arrived in 2015, when the manuscript became the source text for the critical edition work that I carried out at the University of Oklahoma and at the Max Planck Institute in Berlin for the Edition Open Sources Project. ${ }^{7}$

5 Antonio Vallisneri, Primi Itineris per Montes Specimen Physico-Medicum (Manuscript, 1705).

6 See: Francesco Luzzini, "La Tana che urla: cenni di speleologia vallisneriana," in Antonio Vallisneri: la figura, il contesto, le immagini storiografiche, ed. Dario Generali (Florence: Olschki, 2008); Luzzini, "Cavità naturali ed artificiali in Garfagnana e Lunigiana. Le esplorazioni di Antonio Vallisneri," in Antonio Vallisneri dalla Garfagnana alla Scienza, ed. Pietro Rocchi (Lucca: Maria Pacini Fazzi Editore, 2010); Luzzini, "Multa curiosa. Vallisneri's early studies on Earth sciences," Nuncius 26, no. 2 (2011); Luzzini, Il miracolo inutile, 9o-143; Luzzini, "An Uncomfortable, yet Wonderful Journey. Antonio Vallisneri and his Exploration of the Northern Apennines," in Nel nome di Lazzaro. Saggi di storia della scienza e delle istituzioni scientifiche tra ilXVII e il XVIII secolo, ed. Centro Studi Lazzaro Spallanzani (Bologna: Edizioni Pendragon, 2014).

7 Francesco Luzzini, Theory, Practice, and Nature In-between. Antonio Vallisneri's Primi Itineris Specimen (Berlin: Edition Open Access/Max Planck Institute for the History of Science, 2018), http://www.edition-open-sources.org/sources/9/, accessed on 26 April 2021. 


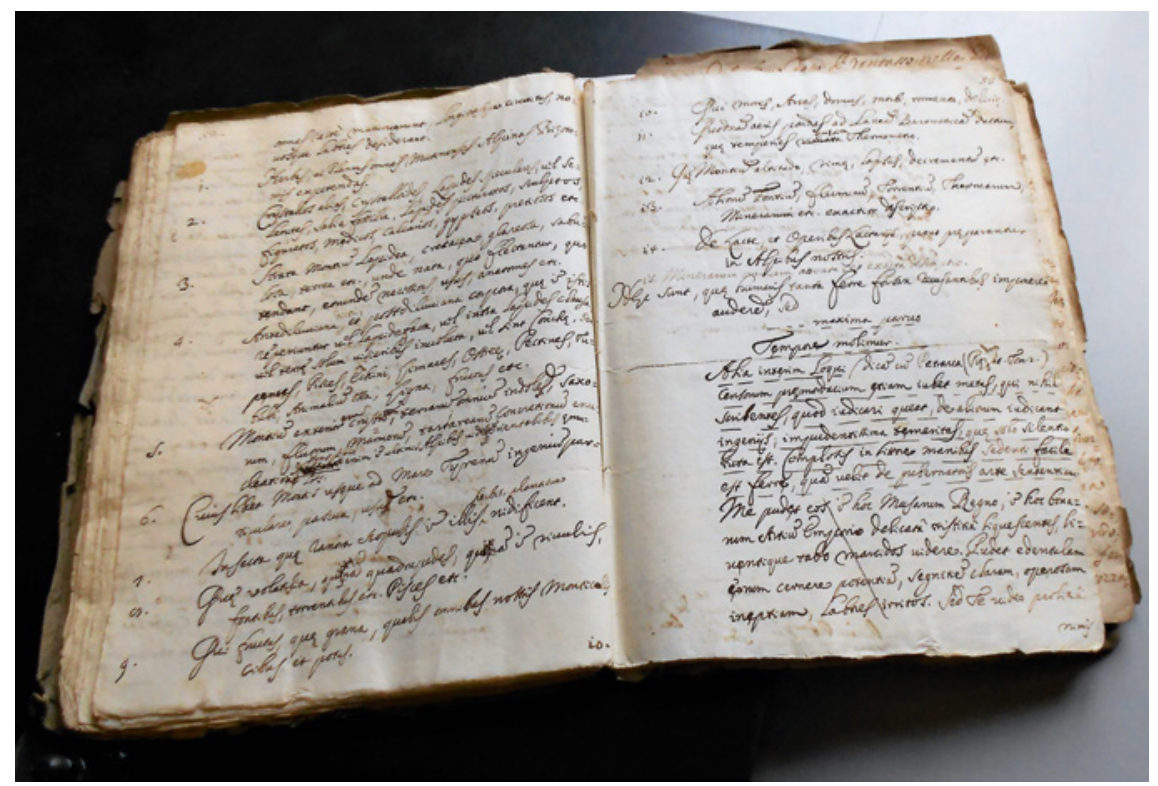

FIGURE 3.1 The draft copy of the "Primi Itineris Specimen". State Archive of Reggio Emilia, Italy, Archivio Vallisneri, 10, "Scritti, minute e appunti scientifici e letterari d'Antonio Vallisneri sr.," mazzo IV, 52-53

As said above, Vallisneri's work had been "furious" - and not euphemistically: the zeal he had poured in the manuscript affected form and content alike. The seamlessly reworked draft (replete with deletions, slips of paper pasted here and there, marginal notes, endless corrections) is the result of an ornate and continuous stylistic effort; and the author's colourful and enthusiastic personality shines through in every inch of this rich text, his subtle and ubiquitous irony being particularly effective at catching the reader's attention.

The Primi Itineris Specimen is the report of a journey embarked on in the summer of 1704, when Vallisneri resolved to travel - with "daring soul," and "trembling foot" - across the "silent horrors" of the northern Apennines. And it is precisely in the description of these "horrors," and in the methods and tools used by the Paduan professor to penetrate their secrets, that the manuscript discloses its greatest value for the history of science. In fact, this document gives us crucial clues to understand a critical stage in the development of methodologies in field research: the moment when Italian experimentalism 
impacted early modern natural philosophy and spread across national and confessional boundaries, expanding its influence on different disciplines.

Vallisneri's route (fig. 3.2) stretched from north-northeast to south-southwest, covering a total distance of about 130 kilometres. From Scandiano, just south of the city of Reggio Emilia, he reached the Alpe di San Pellegrino ("Alp of Saint Peregrine"), one of the highest peaks in the northern Apennines. There he crossed the homonymous pass (which now links the Province of Modena with the Province of Lucca) and descended to Garfagnana. Then he headed west and climbed the valley of the Petrosciana Torrent (a tributary of the Serchio River), and finally reached the Apuan Alps, where he visited the iron mines of Fornovolasco and the cavern known as Tana che urla ("Screaming Cave"). It was in these remote places that he collected conclusive data to support a "great argument"8 of his (which was also the main - though not the only - reason that had induced him to wander in the mountains): a theoretical system on the meteoric origin of springs, triumphantly and thoroughly explained in 1715 in the Lezione Accademica intorno all'Origine delle Fontane ("Academic Lecture on the Origin of Springs"). ${ }^{9}$ By upholding this theory with strong empirical evidence, in this treatise he confirmed measurements and observations

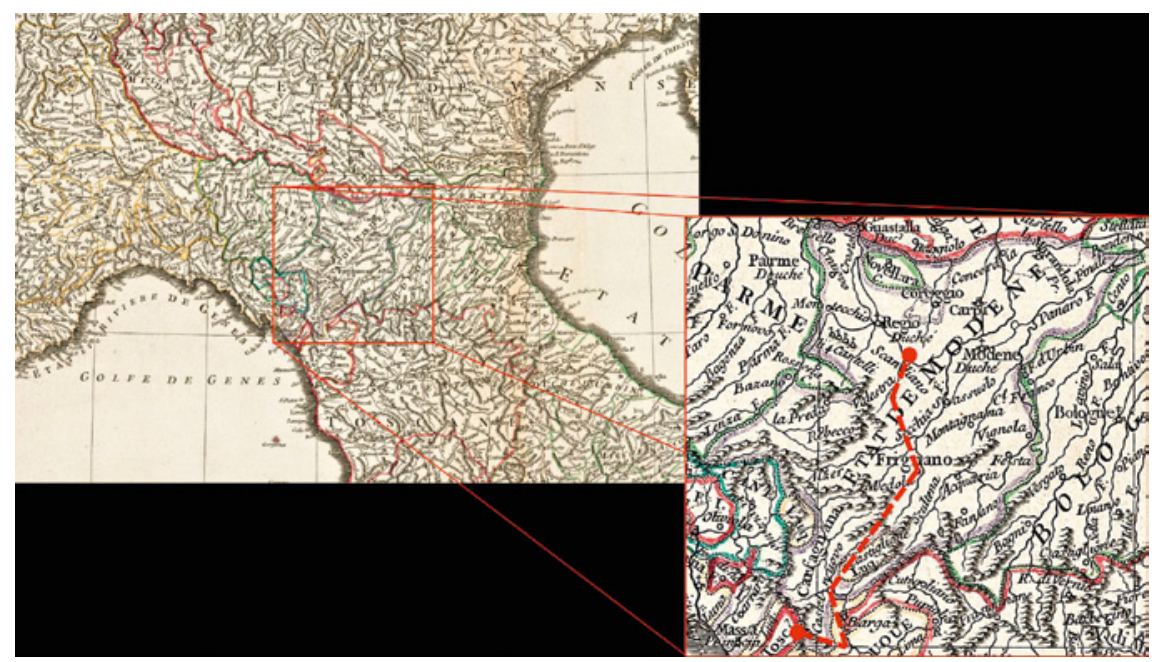

FIGURE 3.2 Northern Italy, the Duchy of Modena and Reggio, and Vallisneri's journey. Original map: "L'Italie: publiée sous les auspices de Monseigneur le Duc d'Orleans", 1743 COURTESY OF THE NORMAN B. LEVENTHAL MAP CENTER AT THE BOSTON PUBLIC LIBRARY, BOSTON (MA), USA

8 Vallisneri, Epistolario, vol. I (1679-1710), 282.

9 Antonio Vallisneri, Lezione Accademica intorno all'Origine delle Fontane (Venezia: Appresso Gio. Gabbriello Ertz, 1715). 
made previously by scholars, engineers, artisans and various experts all over Europe, and dealt a lethal blow to the competing and still far from unpopular theories of a compound origin of fresh water - like, for example, those which assumed the existence of hidden channels connecting the oceans to the earth and the exclusive or partial distillation and/or filtration of sea water through rock strata. ${ }^{10}$

Although unquestionably dominant, however, the origin of springs was not the only issue Vallisneri meant to discuss, given the countless number of natural phenomena that he had been studying over the years and during his journey. And from its very beginning, the Primi Itineris Specimen - with its astoundingly eclectic content - bears eloquent witness to the author's omnivorous curiosity.

The adventure begins among the gypsum layers and the close sulphur mines of Mount Gesso, a hill in the gypsum-sulphur formation of the northern Apennines:11 in this "foul-smelling" cave, Vallisneri observes various kinds of sulphur and other minerals and rocks, and notes down the peculiar terms used by local miners ("canopi") to describe them. ${ }^{12}$ Nor does he omit to discuss the therapeutic properties and uses of that place: indeed, it is an ascertained fact that the sulphur miners from Scandiano live "healthy, to the no small relief of the working people." ${ }^{13}$

After this first set of physico-medical observations, the route continues along the Tresinaro River, heads south and passes through the first slopes of the Emilian Apennines. Five miles past Scandiano, the author faces the barren landscape of the badlands: here, the "grim sight" of the eroded clay soil is enhanced by the "rude variety" of the many colours "wrapping and adorning all the slopes with black, reddish, ferruginous, sallow, white [hues]."14 The

10 On this topic, see: Francesco Luzzini, Il miracolo inutile, 69-161; "Through Dark and Mysterious Paths. Early Modern Science and the Search for the Origin of Springs from the 16th to the 18th Centuries," Earth Sciences History 34, no. 2 (2015).

11 The gypsum layers of Mount Gesso are part of the gypsum-sulphur formation of the northern Apennines, whose evaporitic strata resulted from the Messinian salinity crisis which occurred in the late Miocene epoch (between 5.95 and 5.33 million years ago). During this epoch, a temporary closure of the Strait of Gibraltar made the Mediterranean Sea desiccate almost completely. This event originated the evaporitic rocks which are now visible in this region (http://www.edition-open-access.de/sources/9/8/index.html\#16, accessed on 26 April 2021).

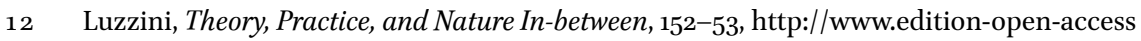
.de/sources/9/8/index.html\# 20 (accessed 26 on April 2021).

13 Ibid., 153, http://www.edition-open-access.de/sources/9/8/index.html\#21 (accessed on 26 April 2021).

14 Ibid., 162, http://www.edition-open-access.de/sources/9/8/index.html\#54 (accessed on 26 April 2021). 
gloominess of this picture is reinforced by another strange phenomenon on the other side of the river, the mysterious "salse": muddy mixtures of salt, water, carbon dioxide, clay, and hydrocarbons that leak from the ground as bubbling, smoking craters. ${ }^{15}$ This "not unsightly source of pleasure" is studied with particular interest by Vallisneri, who is equally devoted to natural philosophy and medicine. He pays attention both to the oddities of these little volcanoes and to the medical properties of their mud, whose virtues he has been testing for years. Their waters, for example, are "a remedy for many diseases proceeding from viscous humours, especially from the cold ones"; and their "salty clay" dispel "tumors, $[\ldots]$ scabies, $[\ldots]$ and stagnant fluid," and is also "beneficial for nerves" and "oedematous legs." 16

On the following day, the author reaches Mount Valestra and then arrives at the ancient and renowned baths of Quara (on the western side of the Dolo Creek). These mineral springs, whose fame dates back to the Roman age and in the fifteenth century were still widely and successfully used, now lie in ruins. Such a pity! Their waters - Vallisneri assures - can treat effectively a number of ailments such as "weak stomach, shortness of breath, flatulence, hypochondria, painful colics, sterility," and even "dizziness, the pain proceeding from slow, especially polypous blood, glutinous phlegm," and many others. ${ }^{17}$ Sadly, none of these remarkable virtues are valued by moderns: and these ancient springs, once renowned all over Europe, are now clogged up with stones, mud, and sand.

The time has come to cross the Dolo Creek and head east. Vallisneri visits the village of Rubbiano, where he meets a family of surgeons known for healing viper bites. They all have a snake-like mark on their shoulders; and, especially in springtime (when the scar has "a brighter colour"), this mark portrays "the rough image of a nest of vipers." ${ }^{18}$ After trying in vain to ascertain

15 A salsa is a phenomenon of secondary volcanism. It is a cold, muddy mixture composed of water, clay, carbon dioxide and hydrocarbons (usually methane and oil) leaking out from the ground. Once the mud reaches the surface, it dries and accumulates, forming little mud volcanoes a few meters tall. The gas leak from the surface is caused by slow and constant movements of the Earth's crust: these trigger the underground sacks in which the mixture is enclosed to open or to compress. The term "salsa" means "salty," as the mixture contains $\mathrm{NaCl}$. Its salinity is equivalent to $1 / 2-1 / 3$ of sea water (http://www.edition -open-access.de/sources/9/8/index.html\#55, accessed on 26 April 2021).

16 Luzzini, Theory, Practice, and Nature In-between, 162-63, http://www.edition-open-access .de/sources/9/8/index.html\#55 (accessed on 26 April 2021).

17 Ibid., 166-67, http://www.edition-open-access.de/sources/9/8/index.html\#66 (accessed on 26 April 2021).

18 Ibid., 167-68, http://www.edition-open-access.de/sources/9/8/index.html\#67 (accessed on 26 April 2021). 
whether or not the image is artificial, the author resumes his journey and comes in sight of the springs of Vitriola, "provided by nature with gratuitous colouring properties."19 These clear and tasteless waters colour the surrounding soil and the aquatic weeds with a "yellowish, ferruginous dye," and are used by the people of the countryside to "blacken linen clothes and wool" (but not without "some previous preparation" whose complex procedures are meticulously described in the manuscript). ${ }^{20}$

The path heads southwest, and finally - after "arduous efforts, and a rough journey" - the Alp of Saint Peregrine, with the homonymous Pass and the village of San Pellegrino in Alpe, comes into sight. ${ }^{21}$ From this privileged viewpoint, a wealth of information is disclosed to Vallisneri's eyes. Although it is the "scorching month of August," winter still rages here "with snow and cold":22 it is now that he reconsiders "the origin of springs and rivers from a higher [perspective]," and his mind follows the "immense mass of water [...] absorbed by underground streams through the darkness of [those] paths." ${ }^{23}$ He realizes that the different nature and arrangement of rock layers is the key to understanding where and how springs emerge. And these considerations, in turn, serve as empirical premises to the next step: $w h y$. In this part of the manuscript, natural philosophy and field research come together in their most refined form, and the core of Vallisneri's theory on the hydrologic cycle is revealed and explained.

From whence the mind is inclined to guess, why the waters hide themselves here, and appear there; why the perennial springs are uncommon here, and the course of rivers is more infrequent, while the both of them flow more abundantly in that [other place]. For this, I thought, is the only circulation of waters (in the bosom of these lands of ours, at least). From

19 Ibid., 168, http://www.edition-open-access.de/sources/9/8/index.html\#68 (accessed on 26 April 2021).

$20 \quad$ Ibid., 168-69, http://www.edition-open-access.de/sources/9/8/index.html\#68 (accessed on 26 April 2021). The village of Vitriola is located in an area delimited by the mountain ridge on which Montefiorino rests (on the west) and by the Dragone Creek (on the east). Arenaceous and calcareous rocks - typically turbidites - dating back to the Campanian, Maastrichtian, and Danian ages (Late Cretaceous-Early Paleocene, 83.5-61.6 Ma) dominate the lithology of this area. Most likely, the colouring properties of the springs described by Vallisneri result from high concentrations of iron oxides in the water.

21 Ibid., 170, http://www.edition-open-access.de/sources/9/8/index.html\#73 (accessed on 26 April 2021).

22 Ibid., 170, http://www.edition-open-access.de/sources/9/8/index.html\# 73 (accessed on 26 April 2021).

23 Ibid., 171, http://www.edition-open-access.de/sources/9/8/index.html\#75 (accessed on 26 April 2021). 
the sky to the earth, from the earth to the sea: and, in turn, from the sea to the sky, from the sky to the earth. That is to say, the cavernous mountains, and the thirsty lands absorb the waters pouring from the sky; [and these waters], flowing for the most part, and absorbed along the way, sink back to the sea through obscure paths. From there, they rise back to the clouds, which make them thin; and from the clouds they descend once more, in a perpetual circulation of the liquid element, whose operation never fails. ${ }^{24}$

After a description of many "crystals and crystal-like" minerals found in these mountains (all of them proving the existence of a "geometric design in nature, and of a somewhat indistinct vegetative power," caused "by an exhalation from the ground"), ${ }^{25}$ the highest summit of the Apennines is crossed. Thereupon, brooks and torrents follow "an opposite course, as if the empire of the waters was divided," ${ }^{26}$ and descend to the Tyrrhenian Sea. At last, the Province of Garfagnana appears to the southwest.

Now natural philosophy merges with the "history of people," 27 and an additional stack of nine papers in the manuscript features a long digression into history, literature, material culture, anthropology, and folklore. This province is bathed by many "perennial and clear torrents, rills, springs, and rivers," and abounds with "most excellent fishes" (trouts, it seems, are particularly delicious). ${ }^{28}$ Its main stream, the Serchio River, runs into the sea about three miles from the estuary of the more famous Arno; and just like its noble neighbour, it is "swollen at times, and threatening." 29 The entire land is "rich in metals" and does not lack for "wheat, wine, hemp, fruits, vegetables, and fishes"; what is more, it flourishes with "plenty of meat, cheese, chestnuts," so that, it is 'sufficiently furnished with the former [goods]' and has "far more than enough

24 Ibid., 172, http://www.edition-open-access.de/sources/9/8/index.html\#75 (accessed on 26 April 2021).

25 Ibid., 174, http://www.edition-open-access.de/sources/9/8/index.html\#8o (accessed on 26 April 2021).

26 Ibid., 175, http://www.edition-open-access.de/sources/9/8/index.html\#81 (accessed on 26 April 2021).

27 Ibid., 177, http://www.edition-open-access.de/sources/9/8/index.html\#84 (accessed on 26 April 2021).

28 Ibid., 180, http://www.edition-open-access.de/sources/9/8/index.html\#91 (accessed on 26 April 2021).

29 Ibid., 181, http://www.edition-open-access.de/sources/9/8/index.html\#91 (accessed on 26 April 2021). 
of the latter ones." 30 As to the inhabitants, the men are usually "short, and - for the most part - dark, muscular, strong, always ready to fight, easily inclined to anger, vengeful, mindful of injuries." ${ }^{31}$ Yet they are also "smart, clever, friendly to strangers, lovers of hospitality, loyal to their lord, inclined to literature, naturally gifted with the most beautiful Tuscan language," and even "cheerful, lively, skilled in mechanics, and constantly engaged in commerce."32 And although these people had suffered "under various lords" in the past, now they live happily "under the rule of the Most Serene House of Este."33

It is now time to return to the main path of natural philosophy. Vallisneri resumes his physico-medical account and describes his descent from the Alp of Saint Peregrine into Garfagnana, where he first reaches the town of Castiglione. After noticing "silvery pyrites from an underground copper and silver mine," and many other mineral and rock samples, he visits the thermal springs known as Bagno della Pieve ${ }^{34}$ and comments on the "amazing properties" of these clear, salty, lukewarm, bituminous waters. ${ }^{35}$ Then he descends to Camporgiano and moves on to Castelnuovo, the administrative centre of the province, and there he observes the ancient and half-ruined Torrite thermal baths. ${ }^{36}$ The path continues south, following the course of the Serchio: once in Gallicano, Antonio heads west along a small tributary of this river (the Petrosciana Torrent) and climbs a steep valley, proceeding towards the western end of Garfagnana. There, among "such precipitous rocky ridges, and [...] high lands, and rough crags," he can see "strong and brawny men living long and happily," and "charming women" who surpass "even the urban Venuses in beauty and in gentle appearance"; and yet, they drink only "clearest water," and

$30 \quad$ Ibid., 182, http://www.edition-open-access.de/sources/9/8/index.html\#98 (accessed on 26 April 2021).

31 Ibid., 182, http://www.edition-open-access.de/sources/9/8/index.html\#99 (accessed on 26 April 2021).

$32 \quad$ Ibid.

33 Ibid., 184, http://www.edition-open-access.de/sources/9/8/index.html\#107 (accessed on 26 April 2021).

34 Bagno della Pieve, a spa in the municipality of Pieve Fosciana (Province of Lucca) (http:// www.edition-open-access.de/sources/9/8/index.html\#138; accessed on 26 April 2021).

35 Luzzini, Theory, Practice, and Nature In-between, 186-188, http://www.edition-open -access.de/sources/9/8/index.html\#137 (accessed on 26 April 2021).

36 Torrite thermal waters, an ancient spa in Castelnuovo di Garfagnana. The spring was located on the western side of the Serchio River, along the Turrite Secca Torrent. It disappeared in 1948, as a consequence of the construction of a nearby hydroelectric power plant (http://www.edition-open-access.de/sources/9/8/index.html\#145; accessed on 26 April 2021). 
fill the "growling stomach" with "rustic food."37 The report lingers for a moment on the (quite intriguing) description of some peculiar habits of that people, who thrive in a land where "neither Minerva, nor Ceres, nor Bacchus" dispensed gifts. ${ }^{38}$ Because of the scarcity of wheat, they prepare starch ("for stiffening linen clothes") from the "arum root,"39 by removing its "external peel" and dissolving its "corrosive salts" with water; and the "shining wite substance" resulting from this process could not be distinguished from common starch. ${ }^{40}$ In "times of famine" they even use it as food, all the "caustic power, and the corrosive strength $[. .$.$] having been absorbed by the aqueous particles." { }^{11}$

At last, the Apuan Alps and the "raging Tyrrhenian Sea" come into view. ${ }^{42}$ Vallisneri enters a small and poor village called Fornovolasco, home to a "hard and most warlike people."43 This place is made up of just some huts and a few houses lying at the foot of the mountains; and not far from there are the renowned iron and vitriol mines, exploited for military purposes on behalf of the Dukes of Este since the second half of the fifteenth century. It seems that many of the workers are descendants of expert miners from the Lombard city of Brescia, whom the Duke Ercole I (1431-1505) hired to find and work the first ore veins: a "non-trivial proof of this" is that many dialect terms from Brescia can still be heard, combined by the "unaware people" with the "gracefulness" of the Tuscan language. ${ }^{44}$

Visiting the mines is not supposed to be an easy, nor a safe task. The village and the nearby tracks are infested with robbers and bandits; and even its inhabitants, according to rumours, have often been an unsafe company to strangers. But here comes an unexpected turn of events. A "certain sagacious youngster"

37 Luzzini, Theory, Practice, and Nature In-between, 191-92, http://www.edition-open-access .de/sources/9/8/index.html\#149 (accessed on 26 April 2021).

38 Ibid., 192, http://www.edition-open-access.de/sources/9/8/index.html\# ${ }_{151}$ (accessed on 26 April 2021).

39 Italian arum, or "gigaro chiaro" (Arum italicum Miller), Family Araceae. It is a herbaceous, perennial plant native to the Mediterranean region, growing 30 to $46 \mathrm{~cm}$ in height (12-18 in). Its tuberous rhizome is particularly rich in starch (http://www.edition-open-access.de/ sources/9/8/index.html\#151, accessed on 26 April 2021).

40 Luzzini, Theory, Practice, and Nature In-between, 192, http://www.edition-open-access.de/ sources/9/8/index.html \#151 (accessed on 26 April 2021).

41 Ibid., 192, http://www.edition-open-access.de/sources/9/8/index.html\#151 (accessed on 26 April 2021).

42 Ibid., 192, http://www.edition-open-access.de/sources/9/8/index.html\#152 (accessed on 26 April 2021).

43 Ibid., 192, http://www.edition-open-access.de/sources/9/8/index.html\#152 (accessed on 26 April 2021).

44 Ibid., 192, http://www.edition-open-access.de/sources/9/8/index.html\#154 (accessed on 26 April 2021). 
steps into the "small inn" where Vallisneri has found (a rather uncomfortable) shelter, covering him with "devoted and trustworthy embraces" and "showing clear signs of joy with his voice and face":

I was amazed at such kindness in such a rude place; and when I asked where so much courtesy [...] could live among crags and caves, he openly revealed that he, too, was a foreigner, and that his name was Domenico de' Corradi d'Austria, superintendent of mines [...]. Since, by an unexpected gift of fate, I was not unknown to him, he invited me to share dinner with him; nor did he want me to spend the night in [that] desolate tavern, which was often unsafe for strangers. As soon as I heard [that] name (which was equally familiar to me), and since it seemed to me that I was imprisoned in [that] cruel inn in the [company] of a deadly gang, or as if I was in a jail, I did not refuse the loyal hospitality and the friendly services of [my] host; and, with the promise of a safe shelter, and with the most pleasant conversation, I restored my energies, drained by the difficult journey. ${ }^{45}$

Domenico de' Corradi d'Austria (1677-1756) was a very expert miner himself, and his knowledge of the Apuan Alps would prove crucial for the success of Vallisneri's underground investigations. In the days that followed he would provide his guest with advice, helpers, equipment and direct assistance, making possible for him to explore the iron mines and the Tana che urla, which still today is one of the most famous caverns in Garfagnana. ${ }^{46}$ There, Vallisneri collected new data for the development of his hydrogeological theory on the origin of springs (and even for other theories, like the controversial one about the existence of seminal and vegetative principles in minerals). ${ }^{47}$ Thus, thanks

45 Ibid., 193, http://www.edition-open-access.de/sources/9/8/index.html\#154 (accessed on 26 April 2021).

46 Ibid., 194-97, http://www.edition-open-access.de/sources/9/8/index.html\#155 (accessed on 26 April 2021).

47 With respect to the debated issue of mineral genesis and growth, Vallisneri's thought (which was strongly influenced by Robert Boyle's corpuscularianism) was not exempt from fluctuations. Though he supposed and - somehow - admitted the existence in minerals of such biological features as seeds (or 'matrices') and nourishment, by the last decade of his life he did not seem to persist in supporting the view of a vegetative power in minerals. On this topic (and, more generally, on the development of the early modern debate on the generation of mineral ores), see: Francesco Luzzini, "Matrices, not Seeds. Vallisneri's Research on Mines: Between Empiricism and Philosophy," in History of Research in Mineral Resources, ed. José Eugenio Ortiz, Octavio Puche, Isabel Rábano, and Luis F. Mazadiego (Madrid: Instituto Geológico y Minero de España, 2011), 109-10; 
to this final adventure in the deepest bowels of the mountains, he felt ready to work on a model of the water cycle that would deal a final blow to the rival theories of alembics and rock filters: for (as he would repeatedly assert ten years later in his Lezione Accademica intorno all'Origine delle Fontane), any origin of springs other than the meteoric was proved wrong by experience, all the "imaginary pipes or supposed gutters"48 being nothing more than the product of vain speculations.

\section{$3 \quad$ Rise of a Method}

Interdisciplinarity can be considered as a dominant feature of the Primi Itineris Specimen. It is no surprise, then, that not even Vallisneri's attempt to define a methodology of field research was exempt from an interdisciplinary approach. In fact, it is in this aspect of his work that lies the key to understanding the methodological and theoretical problems the author faced in this effort - and, therefore, it is here that we can best understand his contribution to the development of Earth sciences and natural history.

Of course, background matters. Vallisneri had studied medicine at the University of Bologna: there he became a proud supporter of Marcello Malpighi (1628-1694) who, together with Francesco Redi (1626-1697), was the leading proponent of the experimental method in those years. Malpighi and his followers had enthusiastically merged experimentalism with the theoretical frameworks of Baconian philosophy and Cartesian mechanism and corpuscularism, extending the influence of Galilean school from physics to medicine and biology. However, this transition did not occur without hurdles. As important studies have explained, in the last decades of the seventeenth century the dispute between experimental and empirical medicine was far from clearly resolved; indeed, the undeniable progress of anatomical knowledge still lacked proven positive effect on people's health. Hence the strong opposition from the advocates of empiricism, such as the Galenic physicians Giovanni Girolamo Sbaraglia (1641-1710) and Paolo Mini (1642-1693) in Bologna; and hence the persistence of traditional therapeutics, essentially based on statistical and empirical criteria.

Luzzini, Il miracolo inutile, 132-37; Luzzini, "Sounding the Depths of Providence: Mineral (Re)Generation and Human-Environment Interaction in the Early Modern Period," Earth Sciences History 39, no. 2 (2020).

48 Luzzini, Theory, Practice, and Nature In-between, 197, http://www.edition-open-access.de/ sources/9/8/index.html \#157 (accessed on 26 April 2021). 
Quite significantly, these methods were still used by even those physicians who rejected the theoretical principles of Hippocratism and Galenism - and both Malpighi and Vallisneri were no exception. ${ }^{49}$ Nor did Vallisneri uncritically reject empirical medicine: during his studies in Bologna, he followed both Sbaraglia's and Malpighi's classes and tried to learn and merge the best of both approaches, although on an ideological level he took the side of experimentalism. However, in carrying on Malpighi's legacy he dared go further, attempting to extend the use of experimental method from medicine to the even more heterogeneous field of natural sciences. This was a transition whose challenge did not lie merely in the different nature of the subject matter: for - and not surprisingly - the very size of this subject matter played a role, too. In fact, for however incredibly complex a human or an animal body could be, it was possible to examine them in laboratories, anatomical theatres, or in other environments where controlled tests could be performed. But this was obviously impossible when studying mountains, caverns, lakes, rivers, and other geological contexts. In these cases, nature could not enter laboratories: therefore, laboratories had to enter - literally - nature.

Following this inverted approach, any savant venturing on the field must necessarily adopt an inverted perspective which, in turn, entailed an interpretive strain that significantly increased the tension between theory and practice. Consequently, both the notion and the method of "experimentalism" had to be reconsidered and reshaped, and its meaning stretched to encompass activities like the exploration and the observation of geological contexts, which were more suitably described as sensorial experiences than as contrived tests. It is not by chance that both the legacy of Galilean experimentalism and traditional empiricism were equally and ubiquitously present in Vallisneri's field research, and they confronted and supported each other in a constant and fruitful dialogue. However, this interaction - which permeates every page of the Primi Itineris Specimen - proved to be as fertile as laden with methodological and epistemological issues; and, in light of this dichotomy, we can also better understand the meaning of a cautious disclaimer at the end of the manuscript, one inviting the reader to

49 On this topic, see: Marta Cavazza, Settecento inquieto: alle origini dell'Istituto delle Scienze di Bologna (Bologna: Il Mulino, 199o), 185-201; Cavazza, "The Uselessness of Anatomy: Mini and Sbaraglia versus Malpighi," in Marcello Malpighi Anatomist and Physician, ed. Domenico Bertoloni Meli (Florence: Olschki, 1997); Claire Crignon, Carsten Zelle, and Nunzio Allocca, eds., Medical Empiricism and Philosophy of Human Nature in the 17th and 18th Century (Leiden/Boston: Brill, 2014); Roger French, Medicine before Science (Cambridge: Cambridge University Press, 2003), 215-21; Generali, Antonio Vallisneri: gli anni della formazione e le prime ricerche, 30-47. 
[...] accept without blame of rashness what I will declare about the fountains, brooks, and rivers of our Alps: that, for the most part, carry their load downstream to the Po [River], all of them owing everything to the rains, and to the melted snows. As to my opinion on the Danube, Rhine, and Rhône Rivers, I am unacquainted [with them]. I am truly astounded at such great names, and can [only] think great things about [their] origin, having not been familiar with their springs. Should we observe with our own eyes [those] enormous mountains, [those] immense regions, and [those] greatest wildernesses, with [their] almost eternal masses of snow, $[\ldots]$ perhaps the astonishment will give way to laughter, and we will not mix the mountains with the sea, nor the seas with the mountains. ${ }^{50}$

Vallisneri was well aware that his quest required "longer journeys and new works," ${ }^{11}$ for his explorations (and, therefore, his experiences) had been chronologically and geographically limited. This was all but a small hurdle, given the kind of audience he was addressing: an international context whose knowledge of Italian science and Galilean experimentalism was far from obvious, and where the notion of uniformity of natural laws across time and space was far from unanimously accepted - being, on the contrary, a matter of ferocious and still unresolved debate. And yet, by the first half of the nineteenth century this concept of uniformitarianism would assert itself as an essential element of science, thanks to the mass of data gathered by countless natural philosophers, scholars, practitioners, and technicians during their experiences on the field. ${ }^{52}$

50 Luzzini, Theory, Practice, and Nature In-between, 197, http://www.edition-open-access.de/ sources/9/8/index.html \#157 (accessed on 26 April 2021).

51 Ibid., 198, http://www.edition-open-access.de/sources/9/8/index.html\#162 (accessed on 26 April 2021).

52 On this topic, see: Luzzini, "Through Dark and Mysterious Paths," 184-85. For an in-depth discussion of the notion of uniformitarianism, see: Claude C. Albritton Jr., The Abyss of Time: Changing Conceptions of the Earth's Antiquity after the Sixteenth Century (San Francisco: Freeman Cooper, 1980), 87-88, 100, 132, 139-47, 186-89, 215; Henry Faul and Carol Faul, It Began with a Stone: A History of Geology from Stone Age to the Age of Plate Tectonics (New York: John Wiley \& Sons, 1983), 89, 90-91, 138, 184, 218; Stephen J. Gould, "Is Uniformitarianism Necessary?" American Journal of Science 263, no. 3 (1965): 22328; David R. Oldroyd, Thinking About the Earth: A History of Ideas in Geology (London: Athlone, 1996), 82, 134, 136-39, 142-43, 177, 202, 301, 330-31; Rappaport, When Geologists were Historians, 95, 162, 164, 167, 205-06, 238-42, 246; Martin J. S. Rudwick, The Meaning of Fossils: Episodes in the History of Paleontology (Chicago, London: The University of Chicago Press, 1972), 110, 130-32, 169-72, 179, 185-88, 231, 235, 259; Davis A. Young, The Biblical Flood: A Case Study of the Church's Response to Extrabiblical Evidence (Grand Rapids: William B. Eerdmans Publishing Company; Carlisle: The Paternoster Press, 1995), $176,178,182,209,246,248,26$ o, 262-63, 270, 285, 29o, 292-93, 296. 
In upholding field research among the members of the European Republic of Letters, Vallisneri clearly aligned himself with the enthusiastic supporters of this still widely neglected way to knowledge, and disclosed a view of immutable harmony of natural laws that would be explained in even greater detail in 1715 with the publication of the seminal Lezione Accademica intorno all'Origine delle Fontane - which, in fact, resumed and extended many concepts and data already featured in the Primi itineris Specimen. In doing so, Vallisneri made a significant contribution to the early development of the debate on uniformitarianism, as well as to the epistemological change produced by this notion in the years to follow.

In accordance with this view, Vallisneri never gave up the ambition to provide his field research with a tool that was as essential and long sought-after as still largely imperfect: a well-defined and univocal methodology to be applied in case of further travels in the mountains. The most eloquent expression of this effort can be found at the end of the manuscript in the form of a detailed list of instructions (or "Index of observations"). According to this prototypical field handbook, a worthy natural philosopher was expected to study and describe a wide array of subjects and objects: from every plant and animal living in the mountains, to the countless and different crystals, fossils, and stones found along the way; from the "stony, chalky, gravelly, sandy layers," to the "outer surface of the mountains" and to the "quality of every soil"; from the "air's weight" and the climate (measured, respectively, with "a barometric device" and with "a thermometer"), to the "height of mountains" and the many different "springs, rivers, torrents, thermal waters, mines." ${ }^{33}$ Nor was the history of people to be passed over in silence, being neither useless, nor unnecessary to describe their different cultures and habits. Thus, for example, it was important to study the use they made of mountains and pastures; which "fruits and grains" were "used as food and drink"; how they prepared "milk and dairy products"; which were their "customs, arts, buildings," and even their "diseases, torments, and delights." 54

The thematic variety of the "Index of observations" is matched by a crowning display of eclecticism in the last papers of the manuscript. Here, natural and human history merge once more in what could be described as a visual celebration of Vallisneri's interdisciplinary attitude: two perfectly preserved,

53 Luzzini, Theory, Practice, and Nature In-between, 198-99, http://www.edition-open-access .de/sources/9/8/index.html\#163 (accessed on 26 April 2021).

54 Ibid., 199, http://www.edition-open-access.de/sources/9/8/index.html\#168 (accessed on 26 April 2021). In the next two decades Vallisneri enriched and refined his "index," whose new version - published in 1726 - listed up to 26 points: Vallisneri, "Continuazione dell'Estratto d'alcune Notizie intorno alla Garfagnana," 404-17. 


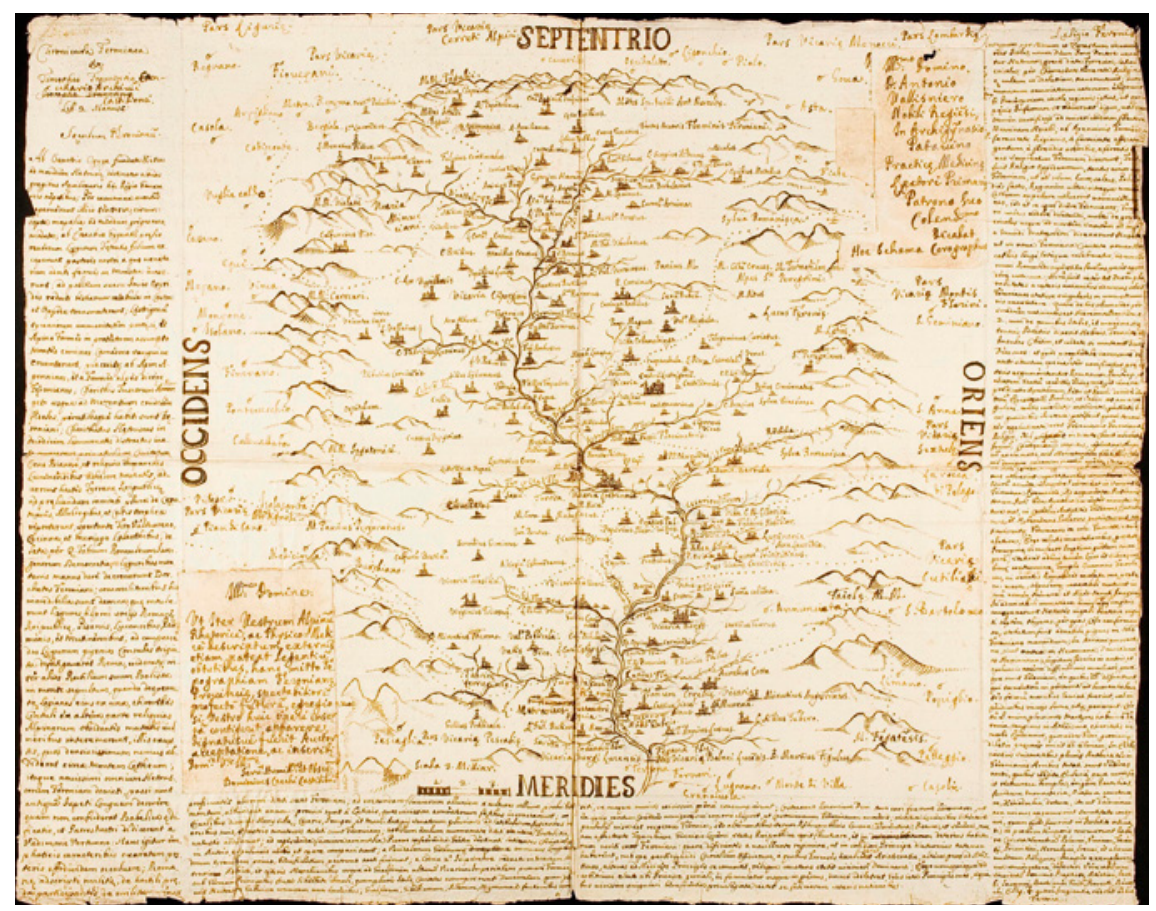

FIGURE 3.3 Primi Itineris Specimen, the map of Garfagnana by Domenico Cecchi IMAGE COURTESY OF THE STATE ARCHIVE OF REGGIO EMILIA, ITALY

hand-drawn maps of Garfagnana. The first one, which is particularly interesting for us (fig. 3.3), bears an autographed dedication by the cartographer Domenico Cecchi (1678-1745). This beautiful document is much more than a simple map, being framed on three sides by a dense text. According to the title, the two quoted passages ("Chronology of Garfagnana" and "Religion of Garfagnana") are from Book 2 of the Silvae Feronianae: a (now lost) manuscript composed by Timoteo Tramonti (ca. 16th-17th century), an antiquarian from Castiglione di Garfagnana ${ }^{55}$ and "Chancellor of the Archive" of this town. ${ }^{56}$ The charming mixture of facts and legends featured in the text provides many literary, religious, folkloristic, mythological anecdotes about the history of the province: from the foundation of the first "fortified huts" and the arrival of Greek heroes and demigods, to the (then) recent dominion of the Princes of Este - passing through the Etruscans kingdoms, the Celts, the Gauls,

55 Currently, this town is part of the Province of Lucca (Tuscany).

56 Luzzini, Theory, Practice, and Nature In-between, 209, http://www.edition-open-sources .org/sources/9/10/index.html\#7 (accessed on 26 April 2021). 
the Romans, the advent of Christianity, the barbarian invasions, the bloody and infamous mediaeval struggles between the Guelphs and the Ghibellines (who "almost destroyed each other and their belongings"), and the exhausting battles for independence against the Republic of Lucca. ${ }^{57}$

In this contribution I have insisted on highlighting Vallisneri's proud support of a unitary view of knowledge, and described this approach as a distinctive feature of his work. It could be argued, reasonably, that interdisciplinarity was all but a peculiar aptitude in the late seventeenth and early eighteenth centuries: at a time when disciplinary boundaries were as fuzzy as enthusiastically crossed, it was relatively common to see doctors, clerics, engineers, alchemists, chief miners, artisans, noblemen, and other (variously) learned scholars and practicians expanding their inquiries beyond the flexible limits of their competencies. Still, as many studies have explained, it is undeniable that Vallisneri's omnivorous curiosity and his ability to recognize and make use of the links between medicine and the many fields of natural philosophy made him an uncommonly versatile scholar even for the standards of his time: to the point that, I believe, it would be reductive to interpret his ambitious work as a mere case of "early modern eclecticism." 58

What is beyond any doubt is that the Primi Itineris Specimen is a worthy expression of the wide-ranging talent of its author. Indeed, it was unfortunate that unknown events doomed the manuscript to such a long oblivion, preventing it from being disclosed to the European Republic of Letters at the proper time. Even more unfortunate, because of the historical and scientific

57 Ibid., 209-215, http://www.edition-open-sources.org/sources/9/10/index.html (accessed on 26 April 2021).

58 See, for example: Generali, Antonio Vallisneri: gli anni della formazione e le prime ricerche; Generali, Antonio Vallisneri: la figura, il contesto, le immagini storiografiche; Generali, "La Repubblica delle Lettere e i carteggi scientifici: il caso di A. Vallisneri"; Luzzini, Il miracolo inutile; Luzzini, Theory, Practice, and Nature In-between, 9-51, http://www.edition -open-sources.org/sources/9/2/index.html (accessed on 26 April 2021); Antonio Vallisneri, Saggio d'Istoria medica, e naturale, colla spiegazione de' nomi, alla medesima spettanti, posti per alfabeto, ed. Massimo Rinaldi (Florence: Olschki, 2012); and, more generally, see the many studies and critical editions produced since 2000 by the National Edition of Antonio Vallisneri's Works (https://www.olschki.it/la-casa-editrice/collane-Olschki/ edizioni-nazionali/edizione-nazionale-Vallisneri, accessed on 26 April 2021; www.vallis neri.it, accessed on 26 April 2021), one of the most lively and renowned cultural institu tions of this kind in Europe. 
significance of this document, which lies not just in the quantity and quality of information it contains, nor in its exceptional thematic variety, but also in its very flaws. It is thanks to these limitations - the many descriptive and lexical inconsistencies, the constant tension between theoretical interpretation and field data, the (unavoidable) methodological awkwardness - that we can fully understand the difficulties faced by the Galilean experimental tradition when it turned its attention from medicine to mountains, venturing in the mare magnum of natural philosophy and setting the basis for an epistemological revolution which, years later, would affect both notions of experimental "verification" and "observation."

As we have seen, this move did not come at no cost. The doubts of the many who questioned the uniformity of natural laws across time and space and the validity of field research for the advancement of human knowledge were not groundless speculations, as the mere concept of "field research" was still far from well defined in the early eighteenth century. Yet, as historians, we can't help but applauding Vallisneri (and the intellectual network he was part of) for his effort to define a methodology of naturalistic experimentalism. For this attempt, in being equally interdisciplinary and unifying, reflects an uncommon awareness of the challenges and ideals that would shape the path of science in the years to come.

\section{Bibliography}

\section{Printed Sources}

Luzzini, Francesco, ed. Theory, Practice, and Nature In-between. Antonio Vallisneri's Primi Itineris Specimen. Berlin: Edition Open Access/Max Planck Institute for the History of Science, 2018. http://www.edition-open-sources.org/sources/9/, accessed on 26 April 2021.

Vallisneri, Antonio. Lezione Accademica intorno all'Origine delle Fontane. Venezia: Appresso Gio. Gabbriello Ertz, 1715.

Vallisneri, Antonio. "Che ogni Italiano debba scrivere in Lingua purgata Italiana, o Toscana." Supplementi al Giornale de' Letterati d'Italia I (1722): 252-330.

Vallisneri, Antonio. "Estratto d'alcune Notizie intorno alla Provincia della Garfagnana, cavate dal primo Viaggio Montano del Sig. Antonio Vallisnieri." Supplementi al Giornale de' Letterati d'Italia II (1722): 270-312.

Vallisneri, Antonio. "Continuazione dell'Estratto d'alcune Notizie intorno alla Garfagnana." Supplementi al Giornale de' Letterati d'Italia III (1726): 376-428.

Vallisneri, Antonio. Epistolario, vol. I (1679-1710), edited by Dario Generali. Milan: Franco Angeli, 1991. 
Vallisneri, Antonio. Saggio d'Istoria medica, e naturale, colla spiegazione de' nomi, alla medesima spettanti, posti per alfabeto, edited by Massimo Rinaldi. Florence: Olschki, 2012.

Vallisneri, Antonio. Che ogni Italiano debba scrivere in Lingua purgata Italiana, edited by Dario Generali. Florence: Olschki, 2013.

\section{Literature}

Albritton, Claude C. Jr. The Abyss of Time: Changing Conceptions of the Earth's Antiquity after the Sixteenth Century. San Francisco: Freeman Cooper, 1980.

Cavazza, Marta. Settecento inquieto: alle origini dell'Istituto delle Scienze di Bologna. Bologna: Il Mulino, 1990.

Cavazza, Marta. "The Uselessness of Anatomy: Mini and Sbaraglia versus Malpighi." In Marcello Malpighi Anatomist and Physician, edited by Domenico Bertoloni Meli, 129-45. Florence: Olschki, 1997.

Crignon, Claire, Carsten Zelle, and Nunzio Allocca, eds. Medical Empiricism and Philosophy of Human Nature in the 17th and 18th Century. Leiden, Boston: Brill, 2014. Faul, Henry and Carol Faul. It Began with a Stone: A History of Geology from Stone Age to the Age of Plate Tectonics. New York: John Wiley \& Sons, 1983.

French, Roger. Medicine before Science. Cambridge, New York: Cambridge University Press, 2003.

Generali, Dario. "Il testo tra comunicazione scientifica e strategie editoriali. Il caso di Antonio Vallisneri." In Edizioni e traduzioni di testi filosofici. Esperienze di lavoro e riflessioni, edited by Marialuisa Baldi and Barbara Faes de Mottoni, 183-205. Milan: Franco Angeli, 2006.

Generali, Dario. Antonio Vallisneri: gli anni della formazione e le prime ricerche. Florence: Olschki, 2007.

Generali, Dario, ed. Antonio Vallisneri: la figura, il contesto, le immagini storiografiche. Florence: Olschki, 2008.

Generali, Dario. "La Repubblica delle Lettere e i carteggi scientifici: il caso di A. Vallisneri." In La Repubblica delle Lettere, il Settecento italiano e la Scuola del secolo $X X I$, edited by Andrea Battistini, Claudio Griggio, and Renzo Rabboni, 43-5o. Pisa, Rome: Fabrizio Serra Editore, 2011.

Gould, Stephen J. "Is Uniformitarianism Necessary?" American Journal of Science 263, no. 3 (1965): 223-28.

Luzzini, Francesco. "La Tana che urla: cenni di speleologia vallisneriana." In Antonio Vallisneri: la figura, il contesto, le immagini storiografiche, edited by Dario Generali, 349-369. Florence: Olschki, 2008.

Luzzini, Francesco. "Cavità naturali ed artificiali in Garfagnana e Lunigiana. Le esplorazioni di Antonio Vallisneri." In Antonio Vallisneri dalla Garfagnana alla Scienza, edited by Pietro Rocchi, 93-124. Lucca: Maria Pacini Fazzi Editore, 2010. 
Luzzini, Francesco. "Matrices, not Seeds. Vallisneri's Research on Mines: Between Empiricism and Philosophy." In History of Research in Mineral Resources, edited by José Eugenio Ortiz, Octavio Puche, Isabel Rábano, and Luis F. Mazadiego, 105-12. Madrid: Instituto Geológico y Minero de España, 2011.

Luzzini, Francesco. "Multa curiosa:Vallisneri's early studies on Earth sciences." Nuncius XXVI, no. 2 (2011): 334-54.

Luzzini, Francesco. Il miracolo inutile. Antonio Vallisneri e le scienze della Terra in Europa tra XVII e XVIII secolo. Florence: Olschki, 2013.

Luzzini, Francesco. "An Uncomfortable, yet Wonderful Journey. Antonio Vallisneri and his Exploration of the Northern Apennines." In Nel nome di Lazzaro. Saggi di storia della scienza e delle istituzioni scientifiche tra il XVII e il XVIII secolo, edited by Centro Studi Lazzaro Spallanzani, 207-20. Bologna: Edizioni Pendragon, 2014.

Luzzini, Francesco. "Through Dark and Mysterious Paths. Early Modern Science and the Search for the Origin of Springs from the 16th to the 18th Centuries." Earth Sciences History 34, no. 2 (2015): 169-89.

Luzzini, Francesco. "Sounding the Depths of Providence: Mineral (Re)Generation and Human-Environment Interaction in the Early Modern Period," Earth Sciences History 39, no. 2 (2020): 389-408.

Oldroyd, David R. Thinking About the Earth: A History of Ideas in Geology. London: Athlone, 1996.

Rappaport, Rhoda. When Geologists were Historians, 1665-1760. Ithaca: Cornell University Press, 1997.

Rudwick, Martin J. S. The Meaning of Fossils: Episodes in the History of Paleontology. Chicago, London: The University of Chicago Press, 1972.

Young, Davis A. The Biblical Flood: A Case Study of the Church's Response to Extrabiblical Evidence. Grand Rapids: William B. Eerdmans Publishing Company; Carlisle: The Paternoster Press, 1995. 